\title{
Needless Necessity: Sameness and Dynamic in Capitalist Society
}

\author{
Marcel Stoetzler
}

In capitalist modernity, all that is fluid is frozen fast, and vice versa. Everything is at the same time solid and not. We need to do something. One must always produce.[1] But then, one must always produce the same. Production is always reproduction, no more, no less, albeit on an extended scale. Capitalist society is a treadmill:[2] "Now, here, you see, it takes all the running you can do, to keep in the same place. If you want to get somewhere else, you must run at least twice as fast as that," as the Red Queen asserted.[3] Society (re-)produces itself, using humans as its principal agents, as ever new and ever the same. Humans (re-)produce society as ever the same by making a fresh start every morning when the alarm bell tolls: a new morning promises gold - the matter of eternity - every single day anew. My consciousness is split on this matter: it tells me, on the one hand, that I have places to go (hooray!), I have some inner growing to do, but at the same time, I am proudly identical to myself (disregarding some metabolism-related corporeal change that one tries to keep separate from one's sense of selfhood). I who took out the student loan yesterday will have to pay up tomorrow, although the intervening time - not least 'the student experience', as they say - will have made me a whole new person (with places to go, hooray!). Growing up, experience - going-beyondand-through: ex-per-ire - or not, contracts are to be fulfilled. This is a rule society will enforce.

This article explores the dialectic of a twofold compulsion characteristic of modern bourgeois society: on the one hand the dynamism grounded in the compulsion to expand production, to never stand still, relax and enjoy, always to increase the labors of self-preservation, on the other hand the static, sameness and identity that are produced by the 'real-abstracting' processes equally central to the capitalist mode of production, the locking down of humans in their identities, including those of sex and race. The article examines these matters through the prism of Adorno's late essay on the concepts of 'static and dynamic' that is taken as a vantage point for a reading of 'The concept of enlightenment' in Horkheimer and Adorno's Dialectic of Enlightenment. The last part of the essay argues that capitalist society's needless necessities impose themselves on society through abstracting practices in everyday life but also produce an equally contradictory set of social movements that have now opened up a fragile prospect for the revolutionary overcoming of capitalist society. The key point of the argument is that Horkheimer and Adorno's unique emphasis on the critique of 'the economic' beyond that of 'the economy' is crucial to this radical perspective.

\section{Ever Expanding Domination is the Identity of Society}

Individuals grow up (or old, rather) but remain the same. An aristocratic class reinvents itself as capitalist in order to remain the same old class of exploiters: modernization. More advanced society means more of the same, but more the same, closure once more, but closer even. Some seek to change the world - put it back on track - in order to preserve it. Capitalism expands to stay the same. It is manically dynamic like no other societal formation has ever been while it is still as dull and repetitive as any that came before. However, capitalist history differs from what preceded it only by degree: society, since its inception, has always tended to expand domination. It has remained identical throughout in at least this one respect: expanding domination of inner and outer nature is what society essentially is. This is society's identity. Contrary to previous more optimistic assumptions, emancipation is not the goal of history but rather an unintended effect of its dynamic that is fiercely struggled for by forces that try to 
slow down, perhaps bring to a halt, the train named telos by bending, mending and complicating the tracks, often exploiting the ironies of history.

Capitalist society has many enemies, and not all of them are good company.[4] Critical theory determines the trajectory of its critique by placing capitalist history into a larger, grander narrative. It says - as Horkheimer did not write - that 'he who is silent on the history of human subjectivity should not talk about capitalism, either' (let alone fascism). This is the premise from which Dialectic of Enlightenment was written. It steps back from a direct critique of capitalist modernity and adopts instead an anthropological perspective that does two important things: one, it rubbishes any attempt to search pre-capitalist history - those golden days when human thinking was still nicely suffused by myth - for the paradise lost that for example the turn-of-the-century 'cultural critics' of capitalist modernity had suggested we should want to return to. Two, it implies that determinate negation of the most negative form of appearance (fascism) of the most negative period (capitalist modernity) of a rather negative overall history (civilization) could just open up a small window on the beginning of actual human history: communism.

\section{From the Critique of the Economy to the Critique of the Economic}

To do this, Horkheimer and Adorno dissolved (conceptually) one of the premises of modern thinking about society, namely the notion that there is this thing called 'the economy' (a sphere separate from and somehow opposed to society, or the social, and the state, or the political), and instead focus on the elementary forms of 'the economic' as they are constituted in the history of human civilization, the capitalist present included. Whereas 'the economy' as a sphere is a rather recent phenomenon (and is likely to disappear, together with capitalism, in the not too distant future), 'the economic' has a much longer history (and threatens to survive the demise of 'the economy').[5] This somewhat indirect critique of capitalism largely bypasses what capitalism has to say about itself in the forms of political economy and economic science. It leads to the surprising result that 'the economic' is exactly what bourgeois apologists, slicing up human society into spheres each with its own logic respectively, say it is not: domination, conventionally assumed to be at home in the political sphere. In Horkheimer and Adorno's analysis, key aspects of domination, gradually emerging throughout human history but getting into their stride in capitalism only, are the rage of production (do!) and the ordering calm of abstraction (be!). They are critiqued from the standpoint of those who long to be calmly, peacefully drifting on water,[6] a.k.a. the standpoint of the proletariat (sellers of labor power who struggle not to be such). Those who in their struggles negate what they are - be they everyday, mundane, struggles that are often invisible to themselves, or else visible, self-declared struggles - are the principle inspiration for dialectical social theory and the figure of the 'non-identical' in particular.

\section{Critical Theory's Method is to Distil Dialectical Concepts Out of Bourgeois Confusions}

The dialectics of modern society are not an arcane secret known only to trained specialists. They are obvious. Every active member of this society can name and describe them if and when forced by circumstances. Dialectical social theory ('Critical Theory'), though, was formulated in circumstances adverse to widespread revolutionary apprehension of societal dynamics - namely in situations following massive historical defeats of emancipatory movements - by some rather bourgeois individuals with a desire to be traitors to their respective classes: sons of industrialists (Engels, Horkheimer) or children from 'educated' and 'lower middle class' families (Marx, Adorno). They developed a theoretical language that is precise, elegant, flexible - hugging rather than imprisoning its referents - but hard hitting, and they did so chiefly by working through the (typically less precise, elegant, flexible, hardhitting) materials produced by some of their (former) classmates who aimed not to betray but to improve and defend bourgeois society: the classic authors of political economy, sociology, psychology - the disciplines of the self-clarification of modern bourgeois society. The critical theorists worked through the latter's writings in a manner often reminiscent of the interpretation of dreams: they sifted out the elements of truth that are contained in them in displaced, hazy, embarrassed, tentative forms.

\section{Adorno's Critique of Comte's False Synthesis of the Concepts Static and Dynamic}

A striking example of this method is Adorno's short meditation on one of the key organizing conceptual dichotomies in the writings of Auguste Comte, who thought that any society is composed of static elements and dynamic elements, which he discussed separately and then sought to bring together in a theoretical synthesis. [7] 
Adorno suggests that this procedure is subject to the same criticism that Marx had directed at Proudhon in The Poverty of Philosophy: 'the false Comtean synthesis ... externally combines what is in fact internally connected merely by its antagonisms.' [8] The static and the dynamic are abstractions from phenomena that are in reality neither or rather, both at the same time. The dialectic of static and dynamic, of sameness and the irresistible pushing forward of change, is key to understanding and, perchance, replacing capitalist modernity with a better one.

\section{Social Statics are Static Only because Abstraction Murdered Them}

Adorno borrows in this essay Marx's famous (Hegel-inspired but anti-Hegel) formulation that 'only abstraction from movement is static - mors immortalis' ('[only] death never dies'): what the philosophers consider to be static is only so because they arrested it, in their minds, by abstracting from, i.e. murdering, movement. Only death never dies: the only thing we can say with certainty to be true eternally is that things change (and in changing, kill off whatever they were the moment before).[9]

With Marx, Adorno proceeds from here, though, to go beyond Marx's critique of Proudhon's philosophical abstractions and points to the truth-content of those abstractions: also abstraction (namely, as Sohn-Rethel would say, 'intellectual abstraction') 'denotes societal reality', namely the reality of - again, in Sohn-Rethel's term - 'realabstraction.'[10] Adorno argues that only one static element has a place in Marx's theory, expressed (between the lines) as 'a negative ontology of antagonistically progressing society': the fact that society still remains 'under the spell of nature' and 'rooted in nature'. Society remains eternally dead as long as it is mere 'prehistory,' not yet human history. It will come to life and defeat mors immortalis when it enters history proper.

The thing that keeps it 'under the spell of nature' and prevents history (i.e. the history of human subjectivity) from beginning is - to use a phrase popular with philosophers - its over-determination by the economic:

Its dynamic, the energetic dissonance, antagonism, is its static, the one thing that has not changed ever yet, and that has destroyed any social relation of production yet. Statically invariant has always been the compulsion to expand (...). Thus, fate has reproduced itself on an extended scale. In order to avoid destruction, every form of society unconsciously works towards its destruction and with it also that of the whole [humanity] that lives on in the form of any society. That was its eternity.[11] Progress that put an end to prehistory would be the end of such a dynamic...[12]

Human history proper, it is implied, would be dynamic but not in a compulsory sense; real human history will spell death for mors immortalis. 'Right society' would overcome both static and dynamic. It would need neither the fetters of any essential beings nor 'blind movement.' Adorno argues that Marx's use of the phrase 'natural laws' when describing historically specific capitalist society points to his notion of their, as it were, naturelikeness, in the specific sense that they belong to human prehistory where humans are not yet in control of society and of themselves. In the same manner he suggests to read the term 'wage slavery' as more than just a metaphor: wage labor is but a rationalized form of appearance of the same old savagery that is slavery.[13]Plus ça change, plus c'est la même chose.

\section{What is Static, Is Probably Already Dead; What is Dynamic, is Not Necessarily Progressing}

Adorno's essay cunningly translates a given conceptual dichotomy (formulated by 'traditional theory') into a dialectical constellation of concepts that illuminates an actual societal-historical dialectic. Comte links the static and the dynamic with order and progress respectively; [14] Adorno throws this neat little system (something Comte himself should have recognized as old-fashioned enlightenment 'metaphysics,' or else, in the jargon of postmodernism, an outdated 'grand narrative') up in the air with relish. The equation of the static and essential sameness with order relies on the assumption that what does not change serves the self-preservation of what exists. Historical evidence shows the opposite, though: societies that become static tend to self-destruct - this is true of all classical empires, but arguably even more so of capitalist society.[15] Likewise, crisis in capitalism should surely come under 'dynamics' but can be filed under 'progress' only in a negative, Hegelian-ironic, dialectical way (i.e. in Marx's sense: capitalism produces its own gravediggers, and in this specific, namely 'ironic' or negatively dialectical sense capitalist progress is human progress). Comte's idea of progress, though, can surely not rely on the actual dynamics of capitalist society (and he knew that, of course - hence his argument for society's need for steering by sociology, the religion of humanity and so on). 'Human nature,' by definition (as 'nature') understood to be static and essential and usually defined in terms of 'natural needs,' is in fact dynamic as human needs are defined societally as much as naturally: human needs are never independent of the ongoing mediation of humans with nature - which is what 'society' is - while the actual shape of society - presently, in human prehistory, yet - is not determined by human needs.[16] Most importantly, perhaps, is traditional social theory's lack of a perspective of transcendence: 'It occurs neither to 
Hegel nor to Comte that antagonistic society, on the strength of its own dynamics, could be transmuted into a higher form, a form more worthy of human beings.'[17] Heteronomous order, characterized by domination, denial and renunciation, has been the invariant nature of all forms of society up to now, and this static, persistent characteristic fuels its dynamism: class struggle.[18] Society's static is 'what drives it onwards.' But it could be otherwise.

\section{Static Reality Produces Static, Ahistorical Reasoning and Kills Time}

At the same time 'reason in its reified form' - the essence of the rationalization underpinning the historical dynamism of human history, hugely intensified in the processes of modernization - is also something static. The 'ahistorical consciousness' that is typical of most contemporaries in developed capitalist societies points to a correspondingly ahistorical, 'static state of reality' that is linked, though, to 'the progressivity and the dynamism of the bourgeois principle' itself, 'universal exchange.'[19] Exchange is timeless, 'just as ratio in mathematical operations in its pure form excretes time.'[20] The two objects that are being exchanged as equivalents are assumed to remain unaffected by time for the duration of the actual exchange process. Adorno adds that time disappears also elsewhere: it is compressed as much as possible in industrial production, and society also does away with memory so as better to adapt to whatever happens to be the cutting edge.[21] Without memory of what came before, though, there can be no consciousness of change: time and history disappear in an endless succession of present moments whose dynamism remains the more invisible the more this dynamism accelerates.

\section{Drastic Reduction of Labor Would Nicely Calm Down the Storming Forward of History}

The dynamic of contemporary human (pre-) history is that of identity: it has remained limited to the onedimensional dynamic of increased domination of internal and external nature, destroying and sabotaging all other potential aspects of dynamic.[22] Change, emancipation even, is possible, though, more than ever before, as Adorno is adamant to emphasize:

Rather than primarily at 'productivity', the rationalization of labor processes could aim at reforming labor itself in a manner worthy of humans, fulfilling and differentiating genuine needs, salvaging nature and its qualitative diversity notwithstanding its being worked upon for human purposes.[23]

The human species has failed so far to become the 'subject of history' as it continues to fall back into nature by dominating it, but 'the immanent unfolding of the productive forces, making human labor superfluous up to a liminal point, contains the potential for change:'[24] the reduction of the quantity of societally necessary labor means that progress does not have to be one-dimensional anymore.

However, this perspective constitutes a threat to the relations of production and thus causes 'the system as a whole mercilessly to lock itself into its monomaniac tendency. Full employment becomes the ideal where labor could cease being the measure of all things.'[25] A static state of things that is based on the continued existence of poverty and scarcity inherently limits its own dynamic transformation to one that serves the progress of domination by the (reformed, reconstituted, dynamicised) societal static itself: Adorno illustrates this assertion with the observation that for example in 'backward' countries, i.e. those perceived as static by the more dynamic ones, the 'seemingly conservative' carriers of the static 'amalgamated themselves with the profitable principle of industrial progress' (one may think of Bismarck Germany as the blueprint for this process).[26] A different kind of static 'could be imagined', though: 'Satiated urge that lets things be the way they are.' But making the transition to the healing, laidback, thoughtful calm of properly human history is no trivial matter: 'History will not calm down as long as it is constituted antagonistically.'[27]

\section{| Horkheimer and Adorno on Self-preservation, Economy and Emancipation}

An alternative to 'the false Comtean synthesis' that Adorno dissected in his essay on 'the static and the dynamic' is provided in Dialectic of Enlightenment. 'The concept of enlightenment,' the book's first main section, treats societal divisions such as 'the economic' as real but not real at the same time while providing a dialectical account of the relationship between 'the economic,' truth and emancipation. Reading the as it were, 'deeper,' anthropological account given in Dialectic of Enlightenment can help unlocking the argument of Adorno's late essay that presupposes the former. In one of its key passages, Horkheimer and Adorno single out as central to Enlightenment philosophy, 
and indeed as 'the true maxim of all Western civilization,' Spinoza's formulation in Ethica, 'conatus sese conservandi primum et unicum virtutis est fundamentum:' 'the endeavor of preserving oneself is the first and only basis of virtue.'[28] This virtue commands: one must preserve oneself, which translates as, there must be economy. It is no recipe for happiness. 'In the judgement of Enlightenment as of Protestantism, those who abandon themselves directly to life, without any rational reference to self-preservation, regress to the prehistoric.' Instinct itself is denounced as 'mythical' as are superstition, thoughtlessness and lust. There is no virtue in any of these.

\section{The Self Mediates Societal Labor, but The Economic Apparatus Shapes the Self}

The emphasis on the concept of self-preservation points to the economic core of enlightenment and civilization:

In the bourgeois economy, every individual's societal labor is mediated by the principle of the self; individualized societal labor yields increments on capital to the ones, the strength for surplus labor to the others. But the more strongly the process of self-preservation is based on the bourgeois division of labor, the more it forces the individuals to alienate their selves, as they have to mold themselves body and soul on the technical apparatus.[29]

This overall civilizational process is continued and intensified rather than interrupted in the period we refer to as 'the Enlightenment':

Enlightened thinking takes account of this, too: finally, the transcendental subject of cognition, as the last reminder of subjectivity, is itself seemingly abolished and replaced by the operations of the self-acting mechanisms of order, which, therefore, run all the more smoothly.[30]

Once enlightenment, virtue and rationality are grounded in self-preservation, the stripping down of the increasingly abstract notion of the self continues to its dismal extreme point in (logical) positivism that abolished even 'the transcendental subject of cognition.' Cognition is now considered a matter of logical processes that are not dependent on subjectivity. Logical positivism has eliminated with thought 'the last intervening agency between individual action and social norm.' After subjectivity has eliminated itself from its own consciousness, it has become 'sachlich' - objective, thingly, value-free - while reason has become 'a universal tool for the fabrication of all other tools.' It is 'single-mindedly trained on a purpose, automatic and outer-directed like the precisely calculated operations of material production', like manual work, subject to a fate it would not dare to challenge.[31] In characteristic fashion, the analogy between reasoning and manual production processes is grounded in the metonymic claim of essential sameness of enlightenment and civilization with 'self-preservation,' i.e. the economic principle.

\section{Logical Positivism is Caveman Philosophy}

From the critique of reason's reduction to a tool for tool making, Horkheimer and Adorno move to a critique of the centrality of formal logic in the context of contemporary logical positivism. They see its hegemony as an outcome of reason's self-limitation to a mere instrument that stems 'in the last instance from the compulsory character of self-preservation.' The latter 'ever again comes down to the choice between survival and death which still reverberates in the principle that from two contradicting propositions only one can be true and only one false.' The most modern philosophical fashion reflects thus a mental reaction that used to be adequate for prehistoric humans who needed to decide in a split second whether to run away or to throw the spear, without ambiguity or the luxury of pondering on shades of grey: in prehistory there was no time for dialectics. This begs the question, of course, why would such caveman philosophy geared toward excluding the middle still seem relevant to many in the twentieth century (and now the twenty-first)? Horkheimer and Adorno answer that this is the work of 'a society in which the maintenance of forms and the preservation of individuals only accidentally coincide. The expulsion of thought from logic ratifies in the lecture hall the reification of human beings in factory and office.' [32]

The fact that society subordinates the preservation of individuals to the preservation of social forms causes logical positivism's concern with form. Excessively formal thinking follows from the preponderance of social forms over social individuals and their concrete needs. Once spirit (as enlightenment) has finally reduced itself to the formal poverty of (logical) positivism, imposing binary caveman thinking: yes/no; kill/run, it goes into reverse and destroys the unfolding of spirit, i.e. itself. The single-minded, ultimately self-destructive, pursuit of self-preservation pure and simple culminates in capitalist crisis and modern warfare. Reason has outlived its usefulness for and is retired by the bourgeoisie. When in developed industrial society 'self-preservation has finally been automated, reason is dismissed by those who, as controllers of production, have taken over its inheritance and fear it in the disinherited:[33] the triumph of increasingly rationalized self-preservation - the economic - leads its ruling class to turn against reason 
because they fear that reason has now jumped ship and gone over to the exploited.

\section{Socialism Surrendered to Reactionary Common Sense When it Separated Spirit from Matter}

Any contemporary attempt to unlock the radical implications of Critical Theory for the benefit of current and future emancipatory transformation of society must take account of the fact that its most sacred text - Dialectic of Enlightenment - is pivoted on a critique of the labor movement: Horkheimer and Adorno begin the final paragraph of 'The concept of enlightenment' with a critique of the latter's insufficient radicalism: 'socialism, in a concession to reactionary common sense, prematurely confirmed as eternal that necessity', namely the necessity of the societal domination that results from the struggle for self-preservation against overwhelming, hostile nature. The domination of nature, though, reflects and extends nature itself whose essence is nothing other than necessity and the struggle for self-preservation, thereby trapping humanity in prehistory: the progress towards history proper, that of humane society reconciled with nature, is arrested.

This domination that socialists falsely believed to be eternal is nothing other than that of 'the economy.' When humanity fights and dominates nature it is nature; when humanity reconciles nature on the basis of acknowledging its own being part of it, it transcends nature. Horkheimer and Adorno argue that socialism 'elevated necessity to being the basis [of society] for all time to come and degraded spirit - in keeping with time-honored idealist tradition - to the pinnacle [of the superstructure], clasping therewith as in a stupor the heritage of bourgeois philosophy.'[34] In other words, the traditionally-Marxist notion[35] that the economy was the 'basis' and that anything to do with thinking was housed upstairs in the 'superstructure' is a continuation of bourgeois thought that 'degrades' spirit by seemingly elevating it out of the realm where it would make a difference, the relationship with nature. We need to drag 'spirit' back down onto the shopfloor not least because embattled, alienated, unreconciled nature keeps striking back at us. In the traditional, in fact bourgeois, socialist perspective, 'the relation of necessity to the realm of freedom remained merely quantitative and mechanical', as socialism was then merely a matter of extending the latter at the expense of the former, whereby nature would continue to be 'posited as entirely alien' as it had been in mythology properly speaking; nature that remained alien and unreconciled, however, was bound to stage a backlash and 'become totalitarian and absorb freedom, socialism included'.[36]

\section{Theory That is as Supple as Intransigent Can Wake Up Society and Inform Emancipatory Praxis: It Only Needs All}

The situation is not entirely without hope, though: 'true praxis capable of overturning the state of things depends on theory's intransigence against the comatose state in which society allows thought to ossify.' It seems that those scattered bits and pieces of thought that escaped reification - such as critical theory, perhaps, or some thoughtful forms of artistic practice - can, by being intransigent, inform 'true praxis' that will shake society out of its coma. Here Horkheimer and Adorno add an attack on the conservative 'critique of civilization' and its reflection in professional sociology: 'Fulfilment is not jeopardized by the material preconditions of fulfilment, unfettered technology as such - this is what those sociologists claim who look now for an antidote, even a collectivist one, to master the antidote.' Technology in itself is not to blame but 'the fault lies with a social context that induces delusional blindness ..., a fortress before which even the revolutionary imagination despises itself as utopianism and degenerates to the compliant trust in the objective tendency of history.' Horkheimer and Adorno encourage here 'the revolutionary imagination' not to capitulate before positivism; positivism, after all, fails to notice the positive fact that humans are the creators of (social) facts.

The text ends on a rather optimistic note: 'In multiplying Gewalt' - the word seems to be used here with the full range of its different meanings: violence, power, force, domination - 'through the mediation of the market, the bourgeois economy has multiplied also its things and forces (Kräfte) to such an extent that their administration no longer requires kings, nor even the bourgeois themselves: it only needs all.' The bourgeois overlords have developed 'things and forces' to such an extent that 'things and forces' transcend their own instrumentality and increasingly look down on their masters. Humans follow their example and 'learn from the power (Macht) of things finally to forgo domination (Macht).[37] 'It only needs all' is probably the understatement of the century, but also one of the most optimistic statements in Dialectic of Enlightenment, which on close reading (and considering the historical context) is a surprisingly cheerful book. Francis Bacon's utopia that 'we should command nature in action' has not only become reality by now but has also revealed itself as the dream (read: nightmare) of perfecting human domination in society. In the process, human knowledge has increased so much, though, that it can begin, finally, to dissolve 
domination for good.[38] No 'Grand Hotel Abgrund' here, at all: instead, a fairly orthodox affirmation of Marxian optimism against the self-induced irrelevance of Marxism.

Reading 'The concept of enlightenment' through 'Static and dynamic' (or the other way round) reveals the radical - but well-obscured - core of Critical Theory: not only (!) the capitalist mode of production needs to be attacked but the concept of labor itself, and not only that: the latter's quasi-anthropological root, the monomaniac compulsion to self-preservation that fails to see that in its excessive success it becomes its own enemy, must be destroyed. At the same time, defeating capitalism will not be possible if the struggle is limited to capitalism's own domain: only through its expansion to the civilizational dimension does this struggle have a chance. The perspective that targets the civilization of compulsory, self-destructive self-preservation, though, includes from the beginning all the things that Marxist theorists for the last half-century have struggled so much to 'bring back in' to their reduced Marxist conceptions: sex/gender, the state, race/nation, and the entire much-quoted 'etcetera.' Thanks to capitalism (and especially its future ending) humanity is now faced with the opportunity to leap out of the state of nature - where self-preservation counts as the basis of virtue - into human history properly speaking. The civilization whose high point is capitalism has created the rational, transcendental subject of cognition, but then rapidly proceeded to destroy it, and critical theory that owes itself to the latter should certainly not applaud this destruction: reason, critique, subjectivity and enlightenment must be defended as they are needed to overcome and reinvent the civilization that created but then stifled them.

\section{Identity and the Capitalist Dynamic through which Identity Forces Itself Upon Humans are Now Needless Necessities and Must Go}

'Malum est in necessitate vivere; sed in necessitate vivere, necessitas nulla est ... Epicurus dixit:' 'Living in necessity is bad, but not a necessity ... said Epicurus.' Marx quoted this assertion by Seneca, paraphrasing Epicurus, in his doctoral dissertation. [39] We can say, by analogy: it is bad that there is economy but it is not itself an economic necessity. This could count as one of the principal propositions of critical theory. 'Living in necessity' - life in the key of self-preservation, of the economic, of restless dynamic and arrested identity - forces us to mold ourselves, body and soul, to the Procrustean bed - the mythological name for what in the industrial process is called a 'stereotype' - of the economy, giving up our 'selves' (to the point of having to ask whether there is such a thing at all) in order to 'preserve ourselves.' [40] A big question follows from here: how does unnecessary necessity impose itself on, and emerge from, our lives, and how can we get rid of it?

\section{Necessity, Economy and Identity Impose Themselves through the Terror of Incessantly Repeated Abstracting Practices in Everyday Life}

Consider the following sad story: one day, in the blistering heat of an English summer, I found myself browsing bookshops (just killing time, really) while I was down to my last fifty pence. In this disagreeable situation, I was confronted with the decision between purchasing a beautifully preserved second-hand copy of Shakespeare's Timon of Athens, which famously contains the insightful appellation of money as

...Thou visible god,

That sold'rest close impossibilities,[41]

And mak'st them kiss; that speak'st with every tongue,

To every purpose! O thou touch[42] of hearts...,[43]

...or a small bottle of water. In an abstracting practice, I was forced to equate book and water as equivalents of the same fifty pence coin. What would have been incomparable without such mediation, had to be compared and evaluated against each other. These 'impossibilities' were being 'sold' red close' and 'made kiss' because '(d)ealing with commodities on an everyday level ... involves ... a continuous act of abstraction'. [44] The handling of money as well as the concern with its absence is a pivotal aspect of everyday life in the modern world (whereas in other forms of society it was limited to specific contexts and events, say, paying the priests or any other protection racket). 
[45] These processes of abstraction, generalization, and homogenisation include that 'activities and products that, in other societies, might not be classified as similar are classified in capitalism as similar,'[46] such as book and water.[47]

The way a society interacts with nature is not in every case constitutive of that society; 'labor in capitalism, however, does constitute that society.' [48] Economy and necessity are necessarily at 'the base' of capitalist society: the complex, dynamic, and polymorphous ensemble of social relations in society dominated by the capitalist mode of production is synthesized and integrated by the daily terror of abstract labor and the exchange of equivalent portions of value.[49] The concept of abstract labor is pivotal for a society mad enough to reduce wealth to value, i.e. to consider worth only that which represents reified human labor, based on the exchange of commodities, in particular, on the exchange of the commodity labor-power.

\section{In the Caveman Logic of Bourgeois Society, the Meaning of Life is Simply its Reproduction}

The ways in which the capitalist dynamic ever again produces sameness include race-making, sex-making and normal-making - racialization, sexing, and normalization - which are processes that naturalize and hypostatize differences. They construct notions of genuineness by breaking up scales of continuous differences that shade into each other into separated, dichotomized, discontinuous pairs of opposites. They are processes of reduction, abstraction, separation and homogenization. The fact that modern bourgeois society acknowledges 'sex' as a valid and relevant social category, structuring both social practice and thought, is a matter of 'gender' in the sense of social meaning that emerges from specific relations of societal practice. The salient question is how does it happen that certain particular bodily differences, chosen from an infinity of eligible differences, are regarded socially significant? Why does it go without saying that human beings fall into exactly two categories that are based on a particular perception of differences between the organs of sexual reproduction? This conception - 'dimorphism' - logically presupposes a worldview that considers biological reproduction central to the meaning of human and social life. One must produce more humans: this imperative must have been a central economic category of human prehistory; today it remains as another instance of bourgeois caveman thinking. Rather ironically - being another aspect of the dialectic of enlightenment - the explicit, conceptually developed version of this tautological caveman perspective - reproduction of life as the meaning of life - was formulated only in bourgeois modernity where sex becomes an essential category, i.e. one that affects the totality of the characteristics of any human being.[50] Sexual dimorphism in this particular sense seems uniquely modern, although it may have been implicit in some of the various and often more fluid conceptions of sex and gender typical of different forms of human society before its global capitalist transformation.[51]

\section{Racism as the Self-defense of Bourgeois Civilization, Economy and Self-preservation}

The society that produced the conditions under which humanity can afford finally to exit its prehistory also produced the practices, institutions and ideologies that so far have most firmly prevented it from following through this possibility. This is the tension that is most painful: humanity's unnecessary, self-imposed suffering, stuck in the ancient mud as in a treadmill, but in full view, just narrowly on the wrong side, of the Gates of Eden. The capitalist mode of production is not the 'origin' or the (historical or logical) 'cause' of the social relations sex and race, and indeed has produced some powerful means to their abolition, but it guarantees their continuing existence (in changing, modernized form) because it is at the same time the barrier to their abolition.

If the perfecting of the techniques of humanity's self-preservation - economy in the widest sense of the word is what civilization is about, then racism is its preventive self-defense. Man the untiring producer, assimilating himself to his own projection of himself as the divine Creator, the earth-subjecting Subject who is divine all but in name, tries to purify humanity from all not so divine, namely unproductive elements incapable of creativity, autonomy and transcendental freedom: 'Exterminate all the brutes!'[52] As the case of antisemitism shows, racism can also take the complementary form of a struggle against groups who are perceived as being too productive, dynamic, modern, capitalist etc., and therewith are feared to endanger the ordered, smooth, pleasingly regular forward march of civilizational progress. Capitalism in its conservative mode wants continuous progress but without rocking the boat too much. Those perceived as over-zealous modernizers may end up in the same camp where nation, state, and capital builders have already sent those they regard as the backward, superstitious, unproductive races.

The rhetoric of creation and productivity (including that of healthy fresh humans) provides a foundation for - typically nationalist - projects of class compromise across the antagonisms that fragment what at the time of the French Revolution still was perceived as the Third Estate. It is built on the cultural memory of all the suffering that 
humanity had to inflict on itself to get this far: now, nearly there, gazes firmly fixed on Paradise, the sails stiff in the winds of progress, one does not want the less civilized, less disciplined, less modern to spoil it all (and especially not such rash, over-keen, über-modern upstarts like 'the Jews' who left savagery behind too rapidly, too recently to make a genuine and responsible contribution to modernity). Those who pride themselves on being creators of the world constantly worry about the danger of falling back behind the achieved status. This danger is incorporated in the dangerous races, enemies within the human species.[53] At the helm of the creation, modern racists fight the dangerous races in order to save humanity and civilization. To the extent that they are aware of the contradiction this constitutes, the racists suffer from bad conscience and concoct sophisticated excuses in the humanities and social sciences; hence scientific racism. The animal rationale must find reasons why 'the animal to be devoured must be evil.'[54] The nation-state in its more liberal guise, however, also has to take into account that level-headed nationals wish to see themselves as being enrolled in a good, patriotic, not a bad, racist nation. This desire is met by multi-culturalist spectacles which the national community performs with well-tempered song and dance while the dangerous races - like the dangerous classes with which they often overlap - are advised not to over-stretch the worried nation's goodwill and tolerance.

\section{Capitalists Call Themselves Producers but are Really just the Exploiters of Old}

The socialist idea that labor is the source of all wealth (which echoes Emanuel Sieyes' bourgeois-revolutionary argument in What is the Third Estate? that only the producers are really constitutive of society) was rejected by Marx in his critique of the Gotha Platform, to which Adorno refers in Negative Dialectic where he states that 'labor is always labor on something' that is non-identical to the subject and its activity: labor adds to the wealth - it 'adds value', in the language of economics - but it does not create wealth on its own.[55] Some wealth, indeed, is just there to be enjoyed without the need for labor to be added (nice fresh air, say); the fact that such wealth is invisible and indeed worthless - not valuable - to the capitalist economy is one of its fundamental flaws.

Horkheimer and Adorno in 'Elements of antisemitism' hint at the bourgeois ideology that underlies the concept of production when they state that the bourgeois 'claimed themselves to be producers while actually remaining the appropriators of old.'[56] The capitalist

called himself producer, but secretly he - like everyone - knew the truth. The notion of the capitalist as producer, whether his profit be legitimized as the reward for entrepreneurship like in liberalism or as the director's salary like today, was the ideology that obscured the essence of the labor contract and the exploitative character of the entire economic system.[57]

The manufacturer has a vital interest in deflecting his responsibility for exploitation, i.e. the exploitation of the workers as a class by the bourgeoisie as a class (who in spite of their modern form of appearance are at bottom nothing but the modernized exploiters of old). The manufacturer points for this purpose to functional differentiations within the bourgeoisie whose different sections have to compete for the magnitude of their respective share of the surplus value appropriated from the workers at the point of production. Horkheimer and Adorno argue that the manufacturers have in the concept of 'productive labor' a powerful ideological instrument - 'productivity' being a core aspect of the ideology that had been used in bourgeois revolutions against backward, unproductive sections of the still feudal aristocracy - that allows them to claim that they receive no more than their just rewards for contributing to production. The extent to which the destructive fury inherent in the bourgeois notion of the subject as creator has shaped modern history, though, has more than fulfilled the prophecy by the 'young-Hegelian' Heinrich Heine that

Kantians will appear ... who with sword and axe will mercilessly rummage around in the soil of our European culture ... Armed Fichteans will enter on the scene, who, in their fanaticism of will, can be restrained neither by fear nor by selfinterest, for they live in the spirit... .[58]

The socialists whom Marx and Adorno later lambasted for their bragging that labor was the source of all wealth (quasi-Fichtean idealists who denied the materiality of the objects of labor) merely tried to copy the revolutionary bourgeoisie's attempt to legitimize their claim to domination by presenting themselves as the producers.

\section{Wealth Can Be Produced Now with Much Less Expenditure of Labor so that Necessity becomes Less Necessary; Social Movements Must Now Cash in Capital's Bonds}

In suffering's countless currencies, humanity has paid plenty into the universal hedge fund of divine justice. 
We have accumulated there a massive and well-deserved pension pot, and rather than paying in more and more, we need now to figure out how to cash it in. The value-form as a core structure of modern society has become increasingly anachronistic as social wealth is becoming more and more independent from direct expenditure of labor: productivity, historically accumulated human knowledge and experience, the worldly afterlife of thousands of past generations, works for the living and could, for the first time in history, free humanity from most of the drudgery, leaving only the (relatively manageable) necessary necessities: man has 'succeeded in making the product of his past labor ... perform gratuitous service on a large scale, like a force of nature.'[59] The capitalist mode of production, though, based on the measurement of riches not as concrete wealth but in the form of abstract value, materialized in money, presupposing the continuously expanding consumption of living human labor, keeps that Golden Age in the bottle.

The main impulses that social movements in modern times up to now followed roughly fall into three categories: a conservative impulse to defend traditional forms (or rather, whatever people consider to be such); a liberal impulse to force modern capitalist society to deliver on its proclaimed ideals ('Liberty, Equality, Property and Bentham');[60] and those - of which we need more - that refer to 'the growing gap between the possibilities generated by capitalism and capitalist actuality' whereby 'actuality' includes ideas and ideals. [61] The third impulse reverses the liberal one by not appealing to supposed good intentions of capital but understanding capital as the Mephistophelian force that always intends evil but unintentionally produces the good, as well.

'The possible reduction of labor to a minimum could not but have a radical effect on the concept of practice.'[62] In a society that has overcome capital, the general large-scale reduction in labor-time and a qualitative change of labor would lead to a conception of work both quantitatively and qualitatively different from labor in capitalist society (as well as different from pre-capitalist drudgery).[63] Labor, reduced to a minimum, would cease being compulsive social mediation. Not having to act would now actually become the summum bonum that the classics had already claimed it to be (while in the present state of barbarism, far niente - doing nothing - presupposes indifference to suffering and is, in this sense, barbaric like 'a talk about trees' in Brecht's poem 'To those born later'). [64] That contemplation is not yet the summum bonum is reflected in the bourgeois ambivalence towards happiness: the bourgeois spirit 'would guarantee the pursuit of happiness to the individual and would have it forbidden by the ethics of labor.'[65] 'Exertions rendered superfluous by the state of the productive forces become objectively irrational.'[66] Critical theory aims at a social order that gives everybody access to the fruits of past labor: past labor must be appropriated in order to liberate the living more and more from having to expend any labor at all. It distinguishes necessary necessities - the interchange with nature; the moderately regular cleaning of toilets - and historically specific, unnecessary necessities dictated by the needs of the capitalist mode of production. Overcoming capitalist society involves getting rid of the latter and rationally regulating the former under common, dignified and laid-back social control.

Working class, women's and minority movements, insofar as their fights aimed at equality and the universal validity of rights, have driven capitalism as far towards its own democratic best self as capitalism itself allowed them to do.[67] They demolished remnants of the ancien régime such as old-style patriarchy or classes-as-milieus that still recalled early-modern estates. Representing the progressive, abstracting, universalizing side of capitalist civilization (which some reactionaries quite perceptively held against them), they collided with its other dimension, namely concrete individual and group specificity. To the extent that they were movements of as much as against-and-beyond capitalist modernity, it was only logical for them to adapt to that other side and to reclaim and reinvent concreteness and particularity. The cold breath of capitalist universality, whose agents they had been, caught up with them. They turned around and reconstructed differences and identities. But the movements that successively and in concert developed to maturity contradictory aspects of advanced capitalist society thereby also created the elements of revolutions to come, i.e. their own negation and that of capitalist society. The dialectic of modern society warrants that all things modern subvert themselves. 


\section{Endnotes}

1. 'Man soll etwas vor sich bringen.' (Horkheimer and Adorno 1986, p. 211). This rather old-fashioned phrase is usually understood to mean 'to acquire wealth' but seems to have originated as a literal translation of the Latin producere.

2. Postone 1993.

3. Carroll 1992, p. 127.

4. Cf. Stoetzler 2012

5. The separations of state, civil society, family and economy that characterize bourgeois modernity are precarious and can be expected to evaporate in the heat of the ever-more intense closure of the totality, continuing a tendency that in the core countries has been underway for more than a century. The diagnosis and examination of this tendency of de-differentiation has been one of the main themes of Critical Theory, and has sometimes led to a somewhat nostalgic glance at the interstices between these (partially antagonistic) 'spheres' that sometimes more, sometimes less, permit the development of strong individuality and the formulation of critique.

6. Adorno 1994, 208; Adorno 1978, 157.

7. In the two middle sections of this article I reconstruct the arguments of selected passages of two key texts, Adorno's "Static" and "dynamic" as sociological categories' and Horkheimer and Adorno's 'The concept of enlightenment.' I dedicate a lot of space to these two texts because methodologically I hold that discussions of canonical authors are the more meaningful the more they are based on detailed readings of exemplary texts that convey a sense of their train of argument rather than selective, and therewith more arbitrary, referencing of various texts from across their oeuvre. As for Critical Theory, Adorno's late essays as well as Dialectic of Enlightenment contain some of the most developed, subtle and condensed, and in this sense, exemplary arguments.

8. Adorno 1975, 40; 1961, 43.

9. Adorno 1975, 40; Adorno 1961, 43. The phrase 'mors immortalis' is from Lucretius' De rerum natura (book 3, line 869; Lucretius 1992, 254-255). The formulation is used by Lucretius to emphasize that life is mortal in the context of his argument that human beings can have sensations and feelings only while alive, namely when body and spirit are 'welded and wedded into one whole.' Once that whole is interrupted, we do not exist, and 'he who is not cannot be miserable.' Even if exactly the same corporeal and spiritual bits and pieces should subsequently come together again being 'welded' into a new living being, this new being would not have recollections from the earlier one who had ceased to exist: although composed of identical elements, the new whole would be non-identical to the previous whole.

10. Adorno 1975, 41; Adorno 1961, 44; Sohn-Rethel 1978; see also Jappe 2013.

11. Adorno uses the past tense here: 'Das war ihre Ewigkeit.' I assume this is a grammar mistake; as the formulation stands it implies that the eternity of mors immortalis has already ended and human history has begun. This would be an unduly optimistic assessment. The following sentence ('Progress...') is in the subjunctive, indicating a possibility not a reality.

12. Adorno 1975, 41; Adorno 1961, 44.

13. Adorno 1975, 42; Adorno 1961, 45.

14. Adorno 1975, 27; Adorno 1961, 35.

15. Adorno 1975, 33; Adorno 1961, 36.

16. Adorno 1975, 30; Adorno 1961, 32.

17. Adorno 1975, 35; Adorno 1961, 38.

18. Adorno 1975, 37; Adorno 1961, 40.

19. Adorno 1975, 38; Adorno 1961, 41.

20. This argument was also made by Sohn-Rethel (1978), with whose work Adorno was familiar.

21. Adorno 1975, 39; Adorno 1961, 42. Spectacles of commemoration as organized by state- and other ideological apparatuses are potent weapons in the destruction of memory (see Dreyfus and Stoetzler 2011).

22. Adorno 1975, 43; Adorno 1961, 46.

23. Adorno 1975, 43; Adorno 1961, 47.

24. Adorno 1975, 44; Adorno 1961, 47.

25. Adorno 1975, 44; Adorno 1961, 47.

26. Love 1996.

27. Adorno 1975, 44-45; Adorno 1961, 48.

28. Horkheimer and Adorno 1986; 1997; 2002: 35; 29; 22.

29. Horkheimer and Adorno 1986; 1997; 2002: 36; 29$30 ; 23$.

30. Horkheimer and Adorno 1986; 1997; 2002: 36; 29$30 ; 23$.

31. Horkheimer and Adorno 1986; 1997; 2002: 36; 30; 23. 
32. Horkheimer and Adorno 1986; 1997; 2002: 37; 30; 23.

33. Horkheimer and Adorno 1986; 1997; 2002: 38; 32; 24-5.

34. Horkheimer and Adorno 1986; 1997; 2002: 47; 41; 32.

35. By this I mean Marxism in the mode of what Horkheimer (1937) had described as 'traditional theory', or else, de-dialecticized, post-critical Marxism.

36. Horkheimer and Adorno 1986; 1997; 2002: 47; 41; 33. The argument that Adorno formulated a critique of 'the economy' that incorporates but goes beyond that of political economy has been made in Dirk Braunstein's outstanding book on Adorno's critique of political economy (Braunstein 2011). For a review of the book in English see Stoetzler (2013).

37. Horkheimer and Adorno 1986; 1997; 2002: 48-9; 42; 33.

38. Horkheimer and Adorno 1986; 1997; 2002: 49; 42; 34.

\section{Marx 1968, p.322.}

40. Procrustes was a vicious character killed by Theseus on his way to Athens. He tortured passers-by with a hammer, stretching their limbs to fit his very large bed. A stereotype is a cast metal printing plate made from a mould; the Greek word 'stereos' means hard, solid, also unfriendly, and is also the root of 'sterile'. In the modern context 'stereo' means three-dimensional.

41. i.e. things otherwise incompatible.

42. i.e. touchstone.

43. This is from act IV, scene 3, lines 389-392. Marx points to this place in Grundrisse (Marx 1973:163).

44. Postone 1993, 175. Postone follows in this respect Sohn-Rethel. In spite of his critique (see below footnote 49) he acknowledges the superiority of Sohn-Rethel's argument over e.g. Grossman's (Postone 1993, p. 177).

45. Protection rackets scare their victims and then offer protection from that scary thing that they may have invented, or exaggerated, or, if it is real, they might themselves be operating or be in cahoots with. Religions that operationalize a notion of an overwhelmingly powerful being beyond our control that needs to be appeased through priestly mediation fit this description, as does the pre-modern state. The modern state does of course a lot more than that, but the contemporary discourse of 'security' assimilates it again to being a protection racket. It often uses other people's religiosity as its (secular) religion, using those others' fanatic-neurotic fetishism (for example 'religious fundamentalism') for its own calculating-cynical fetishism (capitalist rationality).
46. Postone 1993, 153.

47. The everydayness is also emphasized by Adorno when he writes that 'the preponderance of anything objective over the individuals ... can be experienced crassly day after day' (Adorno 1990, p. 300).

48. Postone 1993, 157.

49. Postone (1993) and Jappe (2013) criticize SohnRethel for failing to theorize abstract labor as well as the commodity abstraction. Although this is an important critique, his failure to grasp the concept of 'abstract labor' does not invalidate Sohn-Rethel's main contributions as the issues he is most centrally concerned with - the constitution of abstract thinking and the critique of Kantian a prioris - are not related to capitalism but to the beginnings of commodity production and exchange in classical antiquity and their expansion in early modernity and can therefore not be explained with reference to abstract labor. For the context of developed (industrial) capitalist society, though, Sohn-Rethel's position could be restated and saved - against his dismissal of the concept of abstract labor - by saying that generalized commodity exchange is only conceivable under conditions of generalized wage labor and abstract labor; the exchange of the commodity labor power for wages coincides with the exertion of abstract labor, so that (in developed capitalism) labor itself is a form of commodity exchange: labor power cannot actually be abstracted from labor as its sale does not precede its consumption (although one could interpret the labor contract as the selling in advance of a legal title on that labor power, and as such separate, but that is probably not how most people actually conceive of and experience it).

50. I have discussed these issues in Stoetzler (2008) and (2009).

51. It is possible that the same phenomenon is caused in one context by one set of causes, in another context by another set of causes. A similar argument could be made in regard of race. Asian societies seem to have had a concept of race before the advent of European colonists which must affect the established Marxist argument that the concept of race is a product of European colonialism. However, one needs to look at what exactly the meaning of the concept has been, or is, in the different contexts, and how it emerged and changed. A certain social form (sexual dimorphism; race) may have been arrived at by different societies on different routes but changed its meaning in the process of different societies becoming part of the capitalist world system.

52. Kurtz in Joseph Conrad's Heart of Darkness (Conrad 1996, p. 66; this is near the end of part two of Heart of Darkness).

53. cf. Balibar 1991, 58ff.

54. Adorno 1990, p. 23. 
55. Adorno 1990, p. 178. On Sieyes see Sewell 1994.

56. Horkheimer and Adorno 1986, p. 182.

57. Horkheimer and Adorno 1986, 182-3.

58. Heine 2002, p. 242.

59. Marx 1976, p. 510.

60. Marx 1976, 280.

61. Postone 1993, p. 392.

62. Adorno 1990, p. 244.
63. Postone 1993, p. 362.

64. Brecht 1976, p. 318.

65. Adorno 1990, p. 257.

66. Adorno 1990, p. 349.

67. cf. Postone 1993, p. 369

\section{References}

Adorno, Theodor W., 1961, "Static" and "Dynamic" as Sociological Categories. Translated by H. Kaal'. Diogenes 9:28, p. 28-49

Adorno, Theodor W. 1975 (1961). ,Über Statik und Dynamik als soziologische Kategorien'. In: Gesellschaftstheorie und Kulturkritik. Frankfurt/M: Suhrkamp. 26-45

Adorno, Theodor W. 1978, Minima Moralia, Reflections from damaged life, London: Verso

Adorno, Theodor W. 1990, Negative Dialectic, London: Routledge

Adorno, Theodor W. 1994, Minima Moralia. Reflexionen aus dem beschädigten Leben. Frankfurt: Suhrkamp.

Adorno, Theodor W.; Max Horkheimer, Dialectic of Enlightenment, translated by John Cumming, London: Verso, 1997.

Balibar, Etienne, 1991, 'Racism and Nationalism', in: Balibar, Etienne, and Immanuel Wallerstein, Race, Nation, Class. Ambiguous Identities, London, New York: Verso, 37-67.

Braunstein, Dirk, 2011, Adornos Kritik der politischen Ökonomie. Bielefeld: transcript

Brecht, Brecht, 1976, Poems. Edited by John Willett and Ralph Manheim with the co-operation of Erich Fried. Part Two 1929-1938. London: Eyre Methuen

Carroll, Lewis, 1992, Alice in Wonderland, edited by Donald J. Gray, second edition, New York, London: Norton

Conrad, Joseph, 1996, Heart of Darkness, Complete, Authoritative Text with Biographical and Historical Contexts, etc., second edition, Edited by Ross C Murfin. Boston/ New York: Bedford/ St. Martin's
Dreyfus, Jean-Marc, and Marcel Stoetzler, 2011, 'Holocaust Memory in the Twenty-first Century: between National Reshaping and Globalisation', in: European Review of History: Revue européenne d'histoire 18:1, pp. 69-78f

Heine, Heinrich, 2002, The romantic School and other essays, edited by Jost Hermand and Robert C. Holub, New York: Continuum

Horkheimer, Max, 1937, 'Traditionelle und kritische Theorie', in: Zeitschrift für Sozialforschung, vol 6:2, 245-294.

Horkheimer, Max; Theodor W. Adorno, 1986, Dialektik der Aufklärung, Philosophische Fragmente, Frankfurt/M: Fischer

Horkheimer, Max; Theodor W. Adorno, 2002, Dialectic of Enlightenment, Philosophical Fragments, edited by Gunzelin Schmid Noerr, translated by Edmund Jephcott, Stanford: Stanford University Press

Jappe, Anselm, 2013, 'Sohn-Rethel and the Origin of „Real Abstraction": A Critique of Production or a Critique of Circulation?, in: Historical Materialism 21.1, 3-14.

Love, Joseph L., 1996, Crafting the Third World, Theorizing Underdevelopment in Rumania and Brazil. Stanford: Stanford University Press

Lucretius, 1992, De Rerum Natura, with an English translation by W. H. D. Rouse, revised by Martin Ferguson Smith, Cambridge, Mass: Harvard University Press

Marx, Karl 1976, Capital, vol. 1, London: Penguin

Marx, Karl, 1968, ,Differenz der demokritischen und epikureischen Naturphilosophie nebst einem Anhange', in: Marx Engels Werke Ergänzungsband Teil 1, Berlin: Dietz

Marx, Karl, 1973, Grundrisse, London: Penguin 
Postone, Moishe 1993, Time, Labor and Social Domination, A Reinterpretation of Marx's Critical Theory, Cambridge (Mas): Cambridge University Press

Sewell, William H., 1994, A Rhetoric of Bourgeois Revolution, Stoetzler, Marcel, 2012, 'On the possibility that the revolution The Abbé Sieyes and What is the Third Estate?, Duke University Press Durham/ London

Shakespeare, William, 1970, The Life of Timon of Athens, Harmondsworth: Penguin

Sohn-Rethel, Alfred, 1978, Intellectual and Manual Labour, A Critique of Epistemology, London: Macmillan

Stoetzler, Marcel, 2008, 'Adorno, Non-Identity, Sexuality', in: Tischler, Sergio; Fernando Matamoros; John Holloway (eds.), Negativity and Revolution, Adorno and Political Activism, London (Pluto Press), pp. 151-88
Stoetzler, Marcel, 2009, 'When Nothing is Produced', in mute, culture and politics after the net vol. 2:13, pp. 82-91 that will end capitalism might fail to usher in communism', in: Journal of Classical Sociology 12:2, pp. 191-204

Stoetzler, Marcel, 2013, review of Adornos Kritik der politischen Ökonomie, Dirk Braunstein, 2011, Bielefeld (transcript), British Journal of Sociology 64:3, pp. 549-51 